\title{
FROM SOCIALIST EQUALITY TO CAPITALIST STRATIFICATION: HOW PEOPLE SEE IT
}

FELIX RIEDL ${ }^{1}-M_{A X} H_{A L L E R}^{2}$

\begin{abstract}
The transition from socialism to capitalism has led to diverging socioeconomic outcomes for the Post-Communist countries of Central and Eastern Europe (CEE). While common social problems of capitalist societies were virtually unknown prior to the collapse of socialism, they have been on the increase since the introduction of comprehensive market-oriented reforms. The objective of our article is to investigate the impact of the rising inequality in income in $\mathrm{CEE}$ and the effects of distinct trajectories on the change of individual orientations toward social inequality in Post-Communist East Europe. We present statistical data on structural changes and apply linear and logistic regression on data from the ISSP survey 2009 on the perception of social inequality. Our findings suggest that both individual and structural conditions are relevant for attitudes related to inequality. First, objective inequality itself is not associated with individually perceived income differences. Second, different Post-Communist welfare regimes indicate an effect on such perceptions as well as on the individuals' assessment of the society they live in. Further, the socioeconomic position affects the attitudes toward a redistribution policy.
\end{abstract}

KEYwords Social inequality, equality, social policy, CEE, Eastern Europe, PostCommunist welfare states, economic transition

1 Felix Riedl, graduate student, University of Graz, Austria (Please direct all correspondence to max.haller@uni-graz.at.

2 Max Haller, Professor of Sociology, University of Graz, Austria; email: max.haller@uni-graz.at

Acknowledgements: We would like to thank Philipp Babcicky, Roland Verwiebe and two anonymous reviewers for their helpful comments on earlier versions of this article. 


\section{INTRODUCTION}

The countries of the macro-region widely known as Central and Eastern Europe (CEE) share a common recent history. For several decades of the former century they were governed as state-socialist regimes and represented the ideological, political and economic antagonist of the Western capitalist world. The economies of the socialist-led states were centrally planned and the institution of private ownership was for the most part absent (Bandelj \& Mahutga, 2010: 2136). Among the achievements of this system were strong industrial development and economic growth (particularly in those countries which were least developed before 1917 and 1945, respectively), an educational upgrading of the whole population, full employment and a comprehensive welfare system (Lane, 1971). The adverse features included a retardation of productivity, a slow-down of the increase in the population's living standard compared with Western Europe ${ }^{3}$, and an increasing gap between the population at large and the new ruling class, the Nomenclatura (Djilas, 1957; Voslenski, 1984). State socialism in East Europe collapsed between 1989 and 1991 and with its abolishment new independent nations emerged on the political map. The newborn states rapidly established democratic institutions as well as an economic system based on private property and free markets. In this process they faced major challenges, having to cope simultaneously with differentiation and polarization within a considerably short time span (Lane, 1992; Mikhalev, 2003; Verwiebe \& Wegener, 2000). After a difficult period of transition, however, they are now on a remarkable path of growth and the socio-economic situation and opportunities have been improved considerably.

The reflections that guide the reasoning of this paper are as follows: During the last two decades, the Post-Socialist countries have been transforming toward capitalist market economies and as part of this transformation have also been adapting their systems of social protection. It is evident that the transition process has varied for each country, and thus some of them have achieved a more successful transformation and today are better off economically than others. An important concomitant of this process was that some of these countries have managed to join the European Union and the NATO, while others have formed the Commonwealth of Independent States (CIS) (Aidukaite, 2010: 9). However, there was also another crucial consequence of the transition: Levels of social inequality have been rising dramatically in some of the CEE countries. Starting from these facts, the

3 The GDP of Czechoslovakia, for instance, fell from the level of neighbouring Austria in the late 1940s below that of Greece or Portugal in the 1980s. 
goal of our article is to analyze the impact of the transformation process on orientations and perceptions toward social inequality in these countries.

This article makes use of recent data from the module Social Inequality 2009 of the International Social Survey Programme (ISSP), which included twelve East European Post-Socialist countries: Bulgaria, Croatia, Czech Republic, Estonia, Hungary, Latvia, Poland, Russia, Slovakia, Slovenia, Ukraine and East Germany. The next sections present the theoretical framework and the hypotheses. We then describe the ISSP dataset, variables and methods of analysis and present our empirical findings. The final section concludes with a discussion of the results and their implications.

\section{THEORETICAL FRAMEWORK}

Central and Eastern European countries can be grouped by various socioeconomic features and indicators. For example, one can classify them by their GNP per capita, as demonstrated by Jolanta Aidukaite (2010: 10; see also Haller, 1990). She points out that the majority of the Post-Communist states are characterized through their comparatively low level of income, while a small group of them is better off. Regarding the ISSP-participant countries, Ukraine has a (comparatively) low level of income (or GNP per capita), while Bulgaria, Latvia, and Russia have relatively low incomes; Croatia, the Czech Republic, Slovakia, Poland and Hungary have a rather high income, and Slovenia and East Germany have a high income. Table 1 provides general socioeconomic data (population figures, GDP per capita, life expectancy in years), distinguishing between CEE countries with lower and higher incomes on the basis of the aforementioned reasoning.

The presented figures correspond by and large to the countries' geographical position: Countries closer to Western Europe have higher incomes, people live longer and population development is more stable in comparison with countries further to the East. Such a classification clearly shows considerable variation at the macro level. GDP per capita has increased in most countries, but only weakly in Russia while in the Ukraine it has even decreased. Similar figures appear concerning life expectancy which also increased everywhere except Russia and the Ukraine. The differences in this regard between the CEE countries are huge: Male life expectancy was 63,1 years in Russia in 2010, but 76,3 - 13 years more - in Slovenia. However, even East Germany (the former German Democratic Republic), which experienced the strongest increase in GDP per capita due to massive support from Western Germany, does not fare well in one important indicator: The population has dropped massively from 


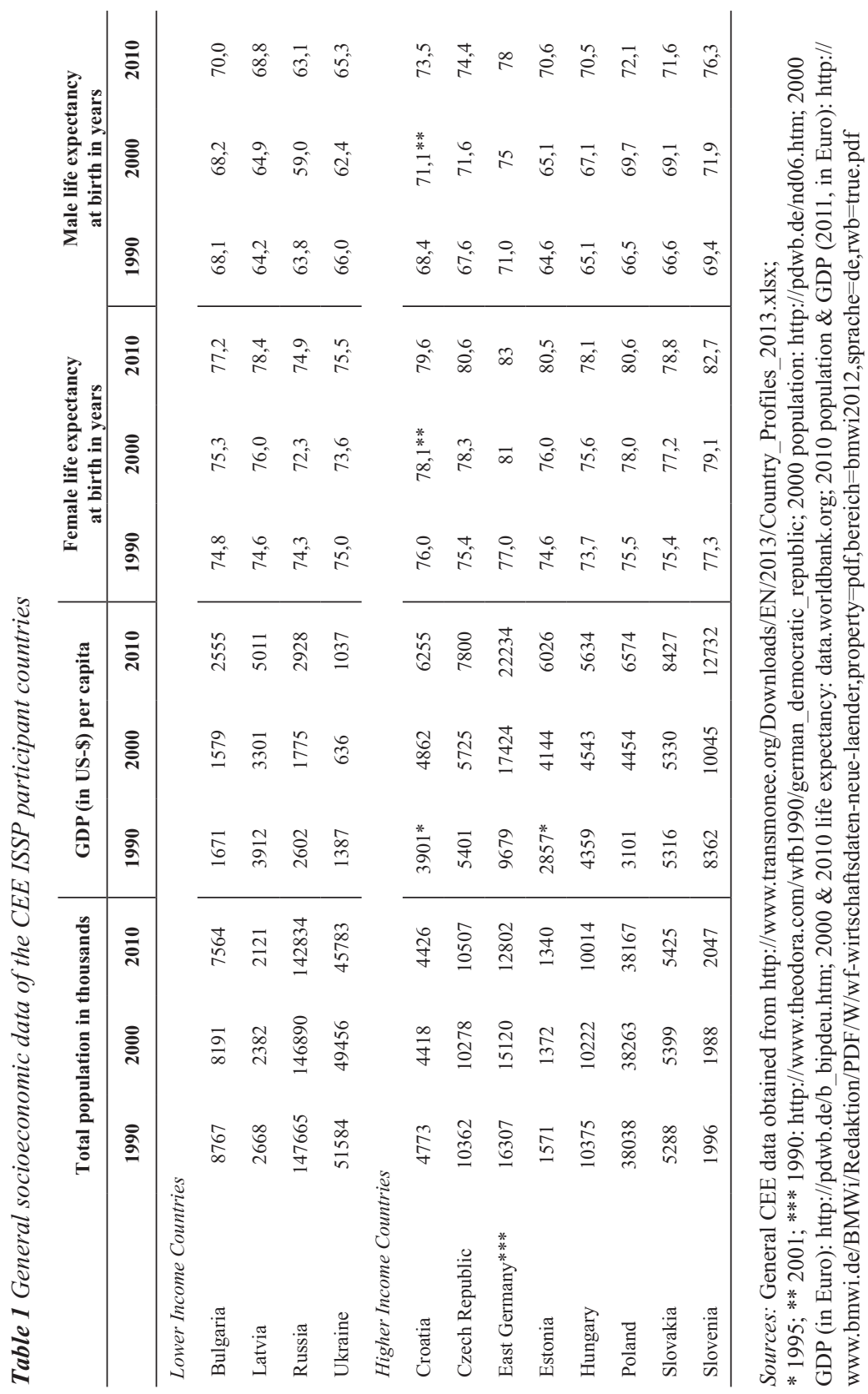


16,3 Million to 12,8 Million people due to a reduction in fertility rates and emigration. Our paper addresses the effect of macro structures on the micro level. The general theoretical proposition is specified as follows:

The process of transition from communism to capitalism in the CEE countries has been taking place on a political, a socioeconomic and a sociocultural level. While the political transformation spawned new political institutions, the socioeconomic transition has led to new emerging forms of social inequality and the ideological transition has engendered new values regarding social justice. These developments have affected the orientation of the population toward social inequality.

Figure 1 illustrates the proposition as a three-level and tripartite temporal structure and indicates the causal relationships between each phase.

Figure 1 General theoretical background proposition
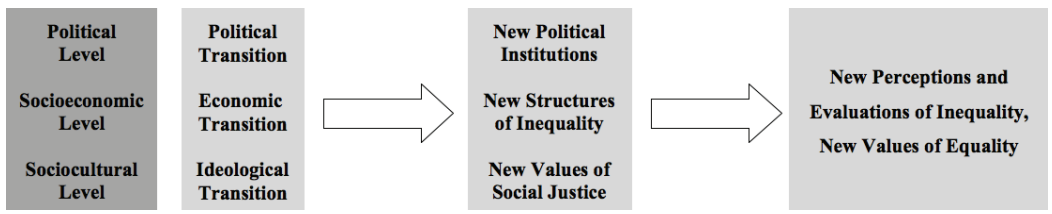

In Europe, the period between 1989 and 1991 was characterized by the "vertiginous decline of communism that culminated in the liberation of Eastern Europe and the break-up of the Soviet Union" (Gros \& Steinherr, 2004: 33). Simultaneously, with the gaining of independence of the CEE countries and the establishment of new nations, the road for economic reforms was paved by policy makers in order to launch the transformation toward market economies. An evaluation of the transition process requires an examination of the question whether the following characteristic features of command economies were successfully abolished: 1. A preference for industry, particularly heavy industry, and a neglect of the service sector; 2. a high level of investment rates for physical and human capital; 3 . the absence of an extended financial sector which allocates savings to investment as well as the virtual absence of interest rates; and 4. the absence of an institutional and legal framework that characterizes a market economy (Gros \& Steinherr, 2004: 117).

In the literature, the transforming CEE countries are basically divided into three categories, i.e. East Germany, CEE countries outside the Former Soviet Union (FSU), and the successor countries of the FSU. East Germany 
fully merged with West Germany in a short time span. ${ }^{4}$ Countries of the second class, most of which are rather small, received much support from the European Union (EU) in order to converge their economies toward the Western market model. The third group of countries suffered from political chaos in the aftermath of communism. Even though each group was facing a different starting point, the common feature of all the countries was the need for a profound transformation and reform program. A successful reform plan had to take into account existing political and economic circumstances; a plan that could be performed successfully say in Poland or Hungary was not necessarily a useful strategy for the Ukraine or Russia (Gros \& Steinherr, 2004: 60-1). Thus the economic reform aims as well as the resulting outcomes varied considerably between the countries. Changing a command economy into a market economy requires price reforms, privatization, financial market reforms, fiscal reforms and changes in the legal framework. Ideally, "all the reforms, or preparations for them, must be launched quickly, even if they take a decade to implement" (Gros \& Steinherr, 2004: 105). However, from the beginning the transition was accompanied by a heated debate over the speed and process of economic reforms around the two opposing approaches of "gradualism" and "shock therapy" as modes of transformation (Ivanova, 2007). Supporters of the gradualist approach claimed that economic growth could only be achieved with a full-scale program of an adequately coordinated and sequenced macroeconomic reform. Advocates of shock therapy believed that an instant economic liberalization in an economy without pre-existing markets was a sufficient condition for the immediate emergence of new markets that would meet every demand (Ivanova, 2007: 169). A clearer understanding of the modes of transition can be achieved with the construction of types of transformation, i.e. the characteristic path of socioeconomic development that a CEE country had to take. Three such types can be distinguished: Stable transformation (e.g. Czech Republic, Hungary), unstable transformation (e.g. Bulgaria, Russia), radical transformation and inclusion into a ready-made state (e.g. East Germany) (Verwiebe \& Wegener, 2000: 126). In order to meet the new emerging needs of the population, the

\footnotetext{
4 East Germany's transformation was entirely piloted by West Germany, and included the adoption of its institutions, political and technical expertise as well as the instant implementation of the encompassing social safety net. Its industrial enterprises were integrated into the world economy overnight (or closed down if highly unprofitable). In this way the basis of competitiveness was destroyed by a dramatic monetary revaluation of $300 \%$ over the course of the monetary union of East and West Germany. $40 \%$ of the previously existing jobs vanished, industrial production dropped, and unemployment increased dramatically (see also Verwiebe \& Wegener, 2000: 132).
} 
phase of economic rebuilding also required adaptations of the social safety net, or to put it another way, the establishment of capitalist welfare states.

In the former Communist countries, problems like poverty or unemployment were considered irrelevant because they were regarded as "solved". Nevertheless, social problems were present and they had adverse effects on particular social groups while, on the other side, a Nomenclatura as an upper class with special privileges did exist (Aidukaite, 2010; see also Djilas, 1957; Voslenski, 1984). Social security was organized primarily through employment because everybody was obliged to work. Housing costs, food and transportation were more or less free; social policies encompassed full employment, free education, and free social services and healthcare. Social security operated as a huge redistributive mechanism that promoted equality between the large social classes and groups. However, after the collapse the shift from a command economy to a market economy challenged its basic pillar, the state's dedication to full employment. In summary, it was not sustainable under the new economic conditions, which led to a massive social restructuring and a decline in the standards of living for many people. Despite the successful performance of the economy, particularly in the emerging private sector, poverty, income inequality, decreasing real incomes, unemployment and high mortality became manifest social problems (Aidukaite, 2010: 8; Arts \& Gijsberts, 1998: 146-7; Verwiebe \& Wegener, 2000: 127; see also Adam, 1999). Ivanova (2007) claims that social inequality in many CEE countries increased due to a combination of economic and social policies, which were in favor of the market-led model of transition that ultimately, however, failed to generate a "trickle-down effect" of economic growth (Ivanova, 2007: 197). Others argue that what actually happened in the first few years of transformation was plainly the neglect of social policy, since it was not considered to be an actual priority. Social protection was undertaken with an ad hoc approach, but eventually since the mid-1990s many governments in CEE spawned welfare reforms in order to meet longterm budgetary and socio-demographic challenges (Sengoku, 2004: 232).

Social reforms in CEE during the transition can be summarized as follows: First, a withdrawal of the state from many activities and services was striven for. Several subsidies and the provision of many public goods and services were either abolished or suspended. Many health-care and social-care services were privatized and activities of voluntary and non-governmental organizations were encouraged by the state. Second, the welfare systems were institutionally pluralized, for example by the separation of social security funds from the state budget, or by the provision of social security by a number of independent institutions. At the same time, the powers and responsibilities 
of regional and local governments were extended (Sengoku, 2004: 232-3). The European Union, the World Bank and the IMF have had a considerable impact on these reforms (Clasen, 2012: 400; Ivanova, 2007: 167, 169). However, these welfare reforms did not match adequately the emerging new social problems. Even though their overall effects have been positive for the social structure of CEE societies, several large social groups were faced with a significant deterioration of their life circumstances. They included individuals with a low-level of education and members of ethnic minorities (e.g. Roma people) who frequently were excluded from the labour market, as well as retired and aged persons whose pensions did not keep pace with rising prices so that their standard of living deteriorated considerably. On the other hand, there were also "winners" of the transformation, particularly the young and healthy citizens with higher levels of education and social capital. Furthermore, regional inequality rose dramatically due to the concentration of wealth and better-paid jobs in urban and more western areas. Being a rural inhabitant in CEE literally became a risk of social exclusion during the last two decades (see also Aidukaite, 2010: 16; Bandelj \& Mahutga, 2010: 2138-40). Nevertheless, social policy experts agree that despite the problems associated with the reforms, public welfare provision in CEE performs better today than one might expect. Labelling the newly-emerging welfare states merely as "residual" might be inappropriate (Aidukaite, 2010: 20; Sengoku, 2004: 234). Similarly, the assumption that these countries constitute one distinct welfare regime has been challenged (Leibrecht et al., 2011).

The CEE countries differ significantly in socioeconomic terms, and the same holds true for the developing systems of their public welfare provision (Fenger, 2007: 13). Therefore, one could explore whether the countries constitute distinct welfare regimes including qualitatively different arrangements between the state, the market, and the family (Esping-Andersen, 1990). Even though his approach was focused on Western countries, Esping-Andersen's typology has been used ever since as a core idea for comparative research on the welfare state. It is thus useful to analyze whether the Post-Socialist countries can be assigned to genuine welfare regimes that are distinguishable from each other, as suggested by Fenger (2007). Following this idea, we propose that three different welfare regime types exist in East Central Europe today, including the following countries from our data set:

1. Post-Communist former Soviet states: Russia, the Baltic states (Latvia, Estonia), Ukraine;

2. Post-Communist East European states: Poland, the Czech and the Slovak Republic, Hungary, Slovenia, Croatia, Bulgaria;

3. Post-Communist German state: East Germany ("Neue Bundesländer"). 
In general, the reasons for the distinction between the first and second group are that state socialism was in existence for around seventy years in the first group, but only about half a century in the latter. Further, the level of development in the second group was higher. This was also true for the German Democratic Republic, which, in addition, experienced a unique process of transition, as outlined before. Most importantly, however, are the insights from the discussion on the development of these countries as welfare states. Scholars in this field view social policy in CEE as a multidimensional phenomenon that is affected by a variety of specific forces in regard to the socio-economic conditions, characteristics of social security institutions, the impact of globalization and Europeanization, and the composition and impact of political elites (Aidukaite, 2011). In general, four groups of scholars can be identified in this regard: The first group asserted that a common Post-Socialist welfare model does not exist, but that the CEE countries developed toward a liberal welfare state. The second group argues that due to institutional differences and varying social and economic performance comparison with established West European welfare state typologies is problematic. The third group addresses the emerging differences among the new (CEE) member states of the EU in order to develop a modification of existing welfarestate typologies. The fourth group argues that aside from some differences, the CEE countries share considerable historical, institutional, and socioeconomic characteristics. Therefore, it is justifiable to speak of distinctive Post-Socialist welfare regimes (Aidukaite, 2011: 216-7). On the basis of a cluster analysis that included indicators of governmental programs (e.g. public expenditure on health, education, the ratio of physicians to inhabitants, levels of individual and corporate taxes, wage level for public servants) and also social situation variables (e.g. GDP growth, life expectancy, unemployment, infant mortality, inflation), Fenger (2007) argues that CEE countries can be grouped into three distinct types of welfare regimes: the Former-USSR type, the Post-Communist European type and the Developing welfare states type. In comparison of these three types, the Post-Communist European countries have the highest revenues from social contributions, the highest government expenditure for health and the highest spending on social protection as well as the lowest level of inflation (Fenger, 2007: 18-9, 23-5). It is important to point out that our own typology largely corresponds with Fenger's (2007), but the properties of our research design necessitate a substantial adaptation: We substitute the Developing welfare states type - which consists, for instance, of Moldova and Georgia - with East Germany as a type on its own for the following reasons. First, its situation is exceptional among the CEE countries and second, our data set does not include countries of the developing type. 
In the preceding section we discussed the dramatic socioeconomic upheaval in CEE during the last two decades. The new public institutions had to tackle the social problems and challenges in terms of new patterns of social inequality. It can be assumed that social perceptions of the conflicting models of transformation and confusing developments have had a crucial impact on the population's attitudes toward equality and social justice. Due to the dramatic effects of the transition, the transformation and transition process in CEE has also raised the attention of inequality research (see also Verwiebe \& Wegener, 2000; Örkény \& Székelyi, 2000). As a result of diverging structural conditions, the different CEE societies are characterized by different forms of inequality, and also by diverging models and methods for the justification, surveillance, and stabilization of inequality (see also Haller et al., 1995: 259). This is mainly achieved by an ideology of social (in)equality and justice. Such an ideology serves at least three purposes: The legitimation of the privileged position of the better off; the provision of a legitimation for the worse off so that they accept their disadvantaged position and adapt to their living conditions; a critique and delegitimation of the existing order of distribution (Hradil, 2002: 223). The main theoretical strands which address the general phenomenon of the justification or delegitimation of inequality are (neo-)functionalist consensus theory and (neo-)marxist and non-Marxist conflict theory. The first claims that a society needs an accordance of beliefs and values in order to function without problems. Conflict theory, however, assumes that individual interests, perceptions and evaluations vary across society because individuals are situated in different positions within the social structure, which makes a consensus in values and beliefs highly unlikely (see also Verwiebe \& Wegener, 2000: 124; Haller et al., 1995: 222-3).

In order to overcome the seemingly theoretical contradictions between these two approaches we assume that two value systems exist in this regard: Primary values based on culture and secondary values based on the location of individuals in socio-structural positions. Most members of a society share primary values because they are grounded in the common cultural heritage and, we may add, in the dominant political system. These values are passed on in the course of socialization. Secondary values differ from one social class and population group to the next, since different groups hold different social-structural positions and thus have diverging interests, perceptions and value orientations (Verwiebe \& Wegener, 2000: 1245). Which patterns of inequality ideologies are likely to be found in the beliefs of a contemporary East European society? We may distinguish here three different types of orientations: People's attitudes can be egalitarian, functionalist, or meritocratic. Egalitarian views advocate substantive equality 
and redistribution, whereas functionalists strongly oppose this idea and thus are anti-egalitarian. Functionalists are also characterized by an emphasis on positive effects of social inequality and a belief in achievement as the basis of unequal rewards. The meritocratic position favors a social order that guarantees the appreciation of high quality work, a good education and equality of opportunity (Haller et al., 1995). We assume that meritocracy is of minor relevance in Post-Socialist societies while functionalism - as the dominant ideology of a market-driven capitalist society - and egalitarianism as the dominant ideology of former communism - are the prevalent ideologies.

\section{HYPOTHESES}

A comparison of Gini coefficients suggests diverging patterns of change of income distribution across the Post-Communist countries. Figure 2 and Table 2 show the progression of Gini-index values for CEE countries between 1986 and 2009. They clearly indicate that income inequality has increased in many of them during this period. Moreover, there is also considerable variation of income inequality between the CEE countries. The trajectories correspond largely to our typology proposed above: The increase of income inequality was modest in most Central East European countries which have been EU member states since 2004 (Croatia, the Czech Republic, Hungary, Poland, Slovakia and Slovenia); it was marked more in Bulgaria and the Post-Soviet countries, irrespective of whether EU member states or not (Latvia, Ukraine, but rather moderate in Estonia). Further, income inequality increased most strongly or, better speaking, exploded, in Russia.

It can be assumed that these strongly-diverging patterns of changes in economic inequality are reflected in subjective perceptions at the individual level. This leads to the first hypothesis: 


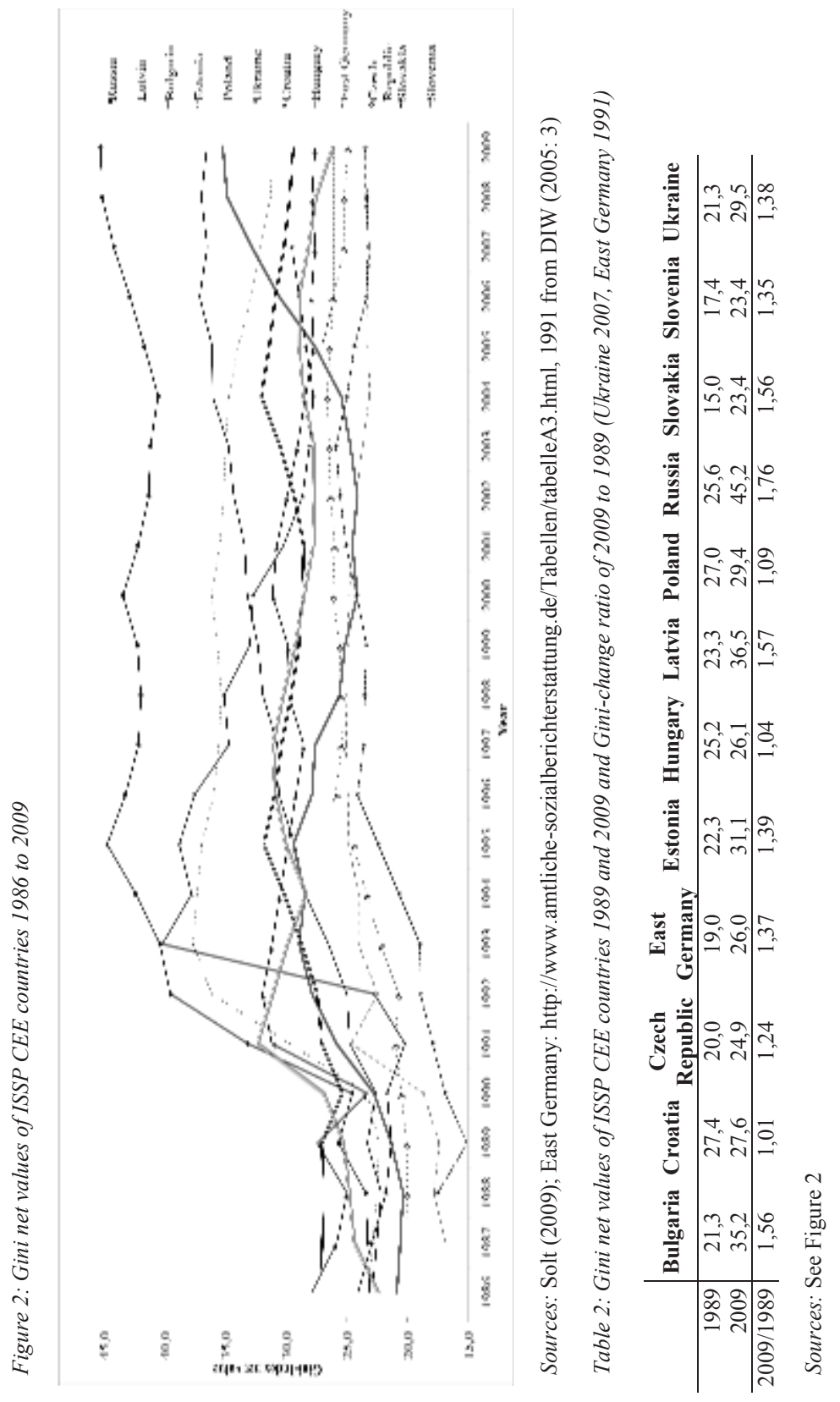


HYPOTHESIS 1: The individual perceptions that differences in income are too large will be higher in countries with high and increasing economic inequality and comparatively lower in countries with moderate or low inequality.

The economic transition has led to diverging outcomes for each CEE country. In the course of these developments, the transforming states also reconstituted their fiscal and administrative systems of public welfare provision, which in turn resulted in distinct types of welfare regimes. The Post-Communist European states have a higher level of public expenditure on health and social protection, a higher level of revenues from social contributions and lower inflation levels than the former Soviet Union countries. The same holds true for East Germany, as it is part of the Federal German Republic that is labelled as a "conservative" welfare state in the literature (Fenger, 2007: 23; see also Esping-Andersen, 1990). In our analysis, we establish East Germany as a distinct type. We assume that the mentioned characteristics of welfare spending and provision are indicative of a welfare state's ability to redistribute income and target the needs of the population. Accordingly, our second hypothesis reads as follows:

HYPOTHESIS 2: Residents of a country belonging to the type of a PostCommunist former Soviet state will be more likely to discern too large income differences in their countries. By contrast, residents of a Post-Communist East European state as well as East Germans will be less likely to perceive too large income differences.

It is evident that the classification of countries in terms of income inequality and type of welfare regime overlaps to a considerable degree (see also Fenger, 2007). In the empirical analysis we will test the two determinants separately and thus we will, at least in part, be able to distinguish between the two effects.

The socio-structural position of an individual is a determinant for beliefs about a just distribution of income and wealth in a society. Accordingly, an individual's personal economic situation and self-evaluation of the social position might also affect beliefs about how the state should be involved in redistribution. Verwiebe \& Wegener (2000: 145) point out that the causal relevance of the structural position increased together with the extent to which a CEE society has converged to Western European societies. They also argue that the impact of cultural (or primary) values has declined; that is, the "old" equality ideology of socialism has lost ground. Considering the three aforementioned major equality ideologies, we suggest that the special 
situation of the transforming CEE societies has led to the prevalence of the ideologies of egalitarianism and functionalism (see also Verwiebe \& Wegener, 2000: 134). This leads to our third hypothesis:

HYPOTHESIS 3: An individual's idea of the state's role in redistribution is a function of its own socioeconomic position in a society. People in higher and privileged positions cling to the functionalist ideology, those in lower and deprived positions to the egalitarian ideology.

Örkény and Székelyi (2000: 201) suggested ti investigate a population's perception of the distribution system as a separate dimension in comparative research on social inequality. In our view, the image of a functioning redistribution system is related to the notion of diverging types of society in terms of stratification. In the ISSP survey of 2009, five different stratification systems or types of societies were presented to the respondents (see Figure 5): An elite-mass model, a pyramid model, an alleviated pyramid, a diamondmodel or middle-class dominated society, and an inverted alleviated pyramid (a society in which upper middle classes dominate). Respondents were asked two questions in regard to these models: First, what they thought their society actually looked like, and, second, which type of society they would prefer. We assume that both the existing income distribution and the institutions of social protection and welfare provision - as described in the motivation for our second hypothesis - have an impact on perceptions of the societal stratification system. Thus, the fourth hypothesis is:

HYPOTHESIS 4: An individual's perception of a particular type of stratified society depends on his/her membership in a particular welfare regime. Thus, people in Post-Soviet countries and people in countries with high economic inequality will see the stratification of their society more as an elite-mass model, but will prefer the inverted pyramid model. People in Central East European countries will perceive their societies mostly as a pyramid, and would prefer a middle-class model.

\section{DATA AND METHODOLOGY}

The following analysis is based on the ISSP module Social Inequality from 2009 (ISSP Research Group, 2012). The original sample consists of 53155 respondents from forty-four countries. Our analysis is carried out on the basis of a sample of 14031 individuals from twelve CEE countries. The three main 
dependent variables (DV) are the perception of too large income differences, the support of income redistribution by the state, which are both described below, and the view of the societal stratification type, as described before. The research questions also require additional typologies and data as system features or macro-social indicators (e.g. Gini coefficients and change ratios, welfare-regime types). Our original intention was to conduct multilevel regression. According to the literature, the number of countries in our research design is suitable for multilevel modelling (Hadler, 2004; Snijders $\&$ Bosker, 2011). This method allows for the nesting of data, which means that the number of individuals within a country is taken into account. Further, the effects and standard errors of macro variables (e.g. Gini index, welfare regime) are estimated on the basis of the number of macro units (i.e. the countries) instead of the total sample size. In this way, multilevel regression provides reliable results (Hadler, 2004, 2005). However, the first stage of our multilevel model was computed and the indicators produced fell short of the critical threshold values. The most important indicator in this regard is the intraclass correlation coefficient. It is recommended that its calculation ought to result in a value between 0.10 and 0.25 (Snijders \& Bosker, 2011: 18), but the values of our model vary between 0.03 and 0.05 . This means that between three and five per cent of the overall variance can be explained by the macro context, which is not sufficient for the proper use of multilevel regression. The alternative approach is linear regression and the use of binary-coded dummy variables that represent the country units (Hadler, 2004: 54).

In order to test Hypothesis 1 to 3, two major linear regressions were computed with SPSS. A logistic regression was calculated for Hypothesis 4. The dependent variables (DV), independent variables (IV), control variables (CV) as well as the coding of all included variables are presented in Table 3. All IV and CV were checked for multicollinearity (see also VIF and tolerance values in the linear regression tables). Each of the regressions is expanded by a second model that considers potential effects of an individual's membership in a particular Post-Socialist country by means of country-dummy variables. This additional regression allows identification of the effects of the country level while taking socio-structural control variables into account. 


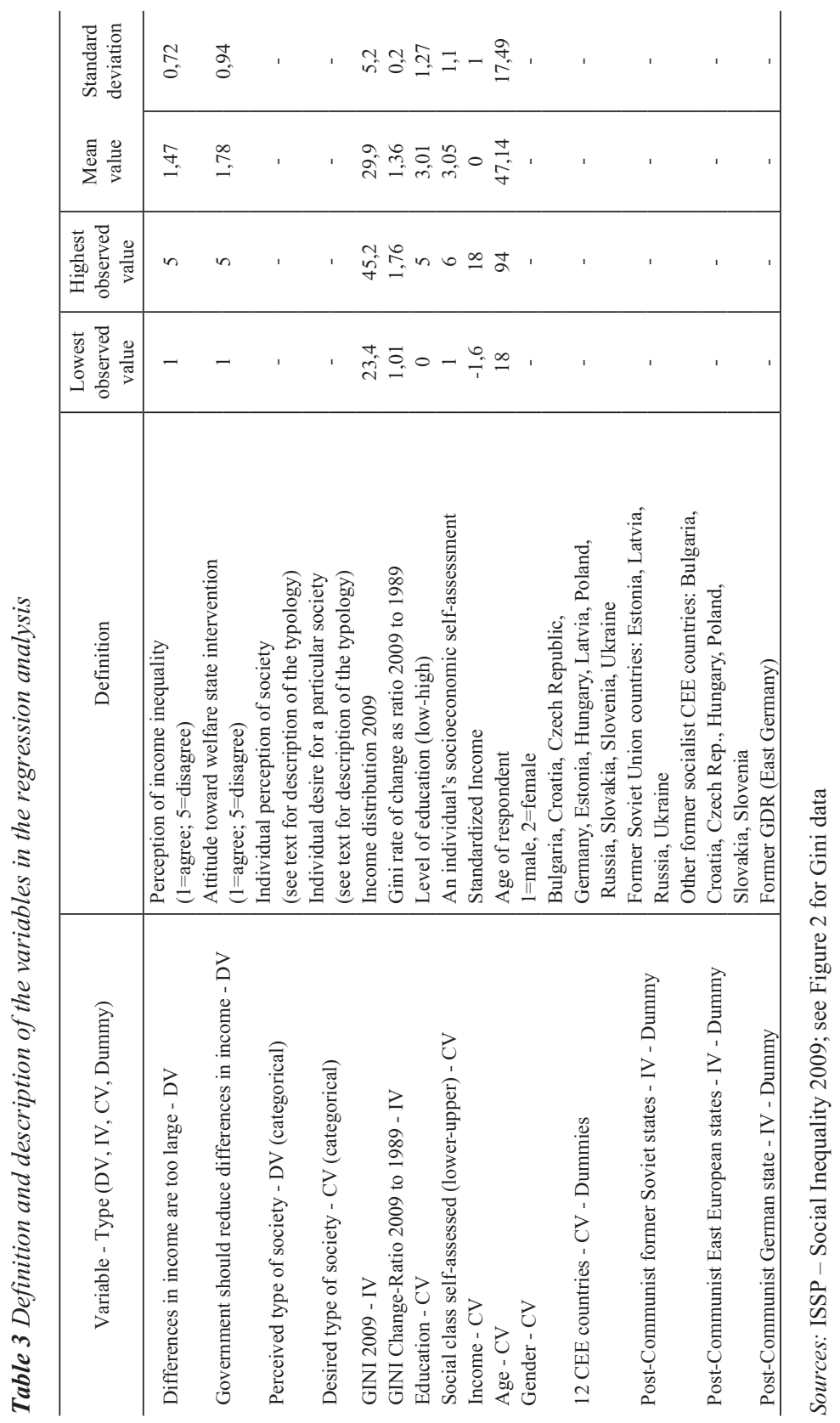




\section{EMPIRICAL RESULTS}

The foci of our paper are the increase and shape of objective inequality across the CEE countries and their impact on the subjective perceptions of inequality. The ISSP survey provides an item that directly addresses this issue which is formulated as follows: "The differences in income are too large" (GESIS, 2008). Respondents can indicate whether they agree or disagree by means of a Likert scale, whereby full consent is coded as 1 and nonconsent is coded as 5. Figure 3 depicts the aggregate relationship between the CEE countries' Gini values of 2009 and the mean values of the individual perceptions of income inequality. Additionally, Figure 4 shows the ratio of the change in income inequality between 1989 and 2009 and the mean values of the inequality perception. Hypothesis 1 claims that the levels of objective inequality are related to the subjective perception of too large differences in income.

Figure 3 CEE Gini-index values 2009 in comparison with mean values of income-inequality perception

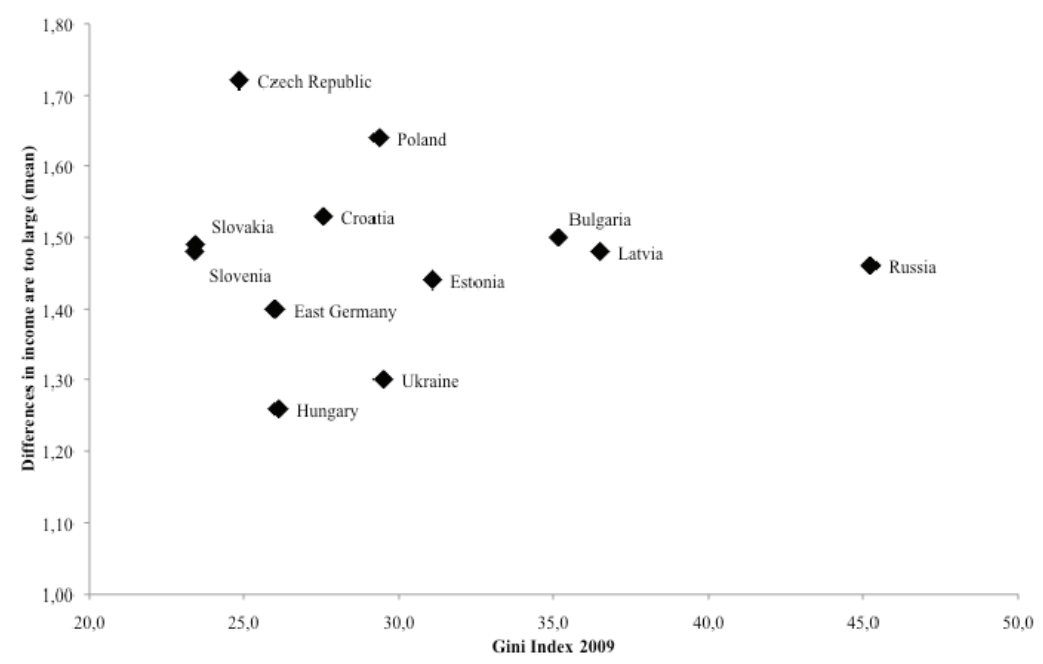

Sources: See Figure 2; Mean values of perception from ISSP - Social Inequality 2009 
Figure 4 CEE Gini-change ratio 2009 to 1989 in comparison with mean values of income-inequality perception

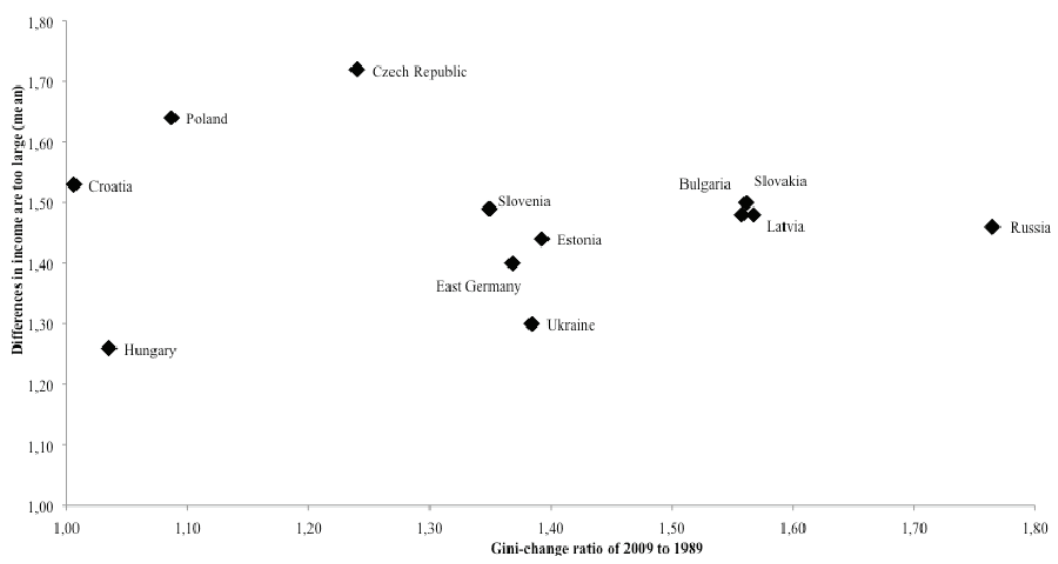

Sources: See Figure 2 and 3

At first glance, the scatterplots do not appear to be in favor of Hypothesis 1; there is no clear pattern that indicates a linear relationship between the level of objective inequality and its subjective perception. Figure 3 shows that the PostSoviet countries - first of all Russia itself - are the most unequal; the perception of the population, however, is only at an intermediate level. This dimension varies strongly. However, between the more Western countries, Hungary has the lowest mean value while the Czech Republic has the highest. The lower the mean value, the stronger is the perception of large income differences. Maybe this reflects the fact that state socialism was more liberal in Hungary, permitting a considerable proportion of private entrepreneurship ("Goulash Communism") while the Communists were very strong in former Czechoslovakia in the first elections after World War $\mathrm{II}^{5}$ and established soon a state-socialist system (see also Večerník, 2009). Likewise, Figure 4 does not indicate a linear relationship between the change in economic inequality (1989-2009) and the perception of it. Regression analysis provides us with a clearer message here; its major advantage is the possibility to include several independent and control variables at the same time in one. This makes it possible to avoid an overestimation or underestimation of the key determinants. We assume that attitudes and behavior are influenced also by the socio-structural position of an individual, and hence it is important to consider the respective control variables.

5 The Communists gained $38 \%$ of the votes in the elections of 1946 . 
Table 4 Linear regression analysis of the perception of too large income differences

\begin{tabular}{|c|c|c|c|c|c|c|}
\hline Model 1: Inequality and Welfare Regimes & B & Sig. & SE & Beta & Tolerance & VIF \\
\hline Constant & 1,137 & & 0,068 & & & \\
\hline \multicolumn{7}{|l|}{ System Characteristics } \\
\hline GINI 2009 & $-0,001$ & & 0,003 & $-0,006$ & 0,696 & 1,437 \\
\hline GINI Change-Ratio 2009 to 1989 & 0,132 & $* *$ & 0,039 & 0,042 & 0,713 & 1,402 \\
\hline Post-Communist East European states & (Ref) & & & & & \\
\hline Post-Communist former Soviet states & $-0,147$ & $* *$ & 0,021 & $-0,101$ & 0,534 & 1,873 \\
\hline Post-Communist German state & $-0,109$ & $* *$ & 0,039 & $-0,031$ & 0,906 & 1,104 \\
\hline \multicolumn{7}{|l|}{ Individual Characteristics } \\
\hline Social class self-assessed & 0,073 & $* *$ & 0,008 & 0,113 & 0,748 & 1,337 \\
\hline Income & 0,022 & $* *$ & 0,008 & 0,031 & 0,81 & 1,234 \\
\hline Education & 0,012 & & 0,007 & 0,022 & 0,633 & 1,58 \\
\hline Age & $-0,001$ & $*$ & 0 & $-0,023$ & 0,934 & 1,071 \\
\hline Gender & $-0,01$ & & 0,016 & $-0,007$ & 0,929 & 1,077 \\
\hline \multicolumn{7}{|l|}{ Model 2: Country Effects } \\
\hline Constant & 1,061 & & 0,048 & & & \\
\hline \multicolumn{7}{|l|}{ Countries $($ Ref $=$ Ukraine $)$} \\
\hline Bulgaria & 0,276 & $* *$ & 0,034 & 0,099 & 0,739 & 1,353 \\
\hline Croatia & 0,216 & $* *$ & 0,033 & 0,088 & 0,617 & 1,619 \\
\hline Czech Republic & 0,392 & $* *$ & 0,031 & 0,168 & 0,609 & 1,643 \\
\hline East Germany & 0,13 & $* *$ & 0,042 & 0,037 & 0,761 & 1,315 \\
\hline Estonia & 0,157 & $* *$ & 0,039 & 0,048 & 0,776 & 1,289 \\
\hline Hungary & 0,032 & & 0,032 & 0,013 & 0,629 & 1,59 \\
\hline Latvia & 0,221 & $* *$ & 0,032 & 0,088 & 0,674 & 1,483 \\
\hline Poland & 0,383 & $* *$ & 0,035 & 0,136 & 0,707 & 1,414 \\
\hline Russia & 0,17 & $* *$ & 0,034 & 0,063 & 0,699 & 1,431 \\
\hline Slovakia & 0,186 & $* *$ & 0,03 & 0,083 & 0,6 & 1,666 \\
\hline Slovenia & 0,166 & $* *$ & 0,033 & 0,064 & 0,657 & 1,523 \\
\hline \multicolumn{7}{|l|}{ Individual Characteristics } \\
\hline Social class self-assessed & 0,063 & $* *$ & 0,008 & 0,098 & 0,696 & 1,437 \\
\hline Income & 0,027 & $* *$ & 0,008 & 0,039 & 0,805 & 1,243 \\
\hline Education & 0,013 & & 0,007 & 0,023 & 0,613 & 1,631 \\
\hline Age & 0 & & 0 & $-0,011$ & 0,894 & 1,118 \\
\hline Gender & $-0,001$ & & 0,015 & $-0,001$ & 0,925 & 1,081 \\
\hline
\end{tabular}

$\mathrm{R}^{2}$ Model 1: 0,029**

$\mathrm{R}^{2}$ Model 2: 0,052**

$\mathrm{N}=8700$

Significance: $* * \mathrm{p} \leq 0.01 * \mathrm{p} \leq 0.05$

Data: See Table 3 
According to Table 4, the impact of the level of objective inequality is weak in comparison with an individual's own class background. Being a member of a higher socioeconomic class (according to one's own self-assessment) corresponds with a stronger rejection of the belief that inequality is too high, the dependent variable (DV). Also personal income has a significant effect on this belief or perception, albeit its Beta value is at a much lower level. In other words, people who are better off less frequently think that income differences in their country are too large. Interestingly, the impact of the level of income inequality in 2009 is statistically insignificant while the change ratio between 1989 and 2009 is significant and has the third highest Beta value. It indicates, however, a positive correlation with the DV. Thus, the data contradict the assumption of Hypothesis 1: They suggest that individuals from a country with increasing inequality do not tend to have the impression of too large income differences in their country.

The regression model indicates, however, strong support for Hypothesis 2. Controlling for the impact of the individual social position, the effect of membership in one of the CEE welfare regimes is statistically significant and strong (Model 1 in Table 4). The dummies for the Post-Communist former Soviet state and Post-Communist German state are both statistically significant and negatively correlated with the DV, whereas the former has a much higher Beta value than the latter. Individuals who live in a country within those distinct welfare regimes are coded as 1 . This means that they indeed tend to share the belief that large differences in income exist in their countries. It also supports Hypothesis 2 by showing that people within the former Soviet Union have a stronger tendency to perceive large differences in income. It can be argued that people within the Post-Communist East European states do not tend to claim that large income differences exist, since they are coded as 0 . Therefore, Hypothesis 2 is supported across all CEE countries. Model 2 in Table 4 reveals the country-level effect on the DV. Here we can see that particularly people in the Czech Republic and Poland exhibit the strongest tendency to reject the idea of large income differences in their countries.

Hypothesis 3 can be tested with the regression model presented in Table 5. The hypothesis claims a strong relationship between an individual's socioeconomic position and his or her attitude toward redistribution by the welfare state. The DV is formulated in the following way: "It is the responsibility of the government to reduce differences in income". Here, too, the respondents can state their consent or non-consent on a Likert scale, with full consent coded as 1 and rejection coded as 5 . 
Table 5: Linear regression analysis of the attitude toward the reduction of income differences

\begin{tabular}{|c|c|c|c|c|c|c|}
\hline Model 1: Inequality and Welfare Regimes & $\mathrm{B}$ & Sig. & SE & Beta & Tolerance & VIF \\
\hline Constant & 1,274 & & 0,091 & & & \\
\hline \multicolumn{7}{|l|}{ System Characteristics } \\
\hline GINI 2009 & 0,007 & & 0,004 & 0,023 & 0,699 & 1,431 \\
\hline GINI Change-Ratio 2009 to 1989 & 0,225 & $* *$ & 0,053 & 0,053 & 0,71 & 1,408 \\
\hline Post-Communist East European states & (Ref) & & & & & \\
\hline Post-Communist former Soviet states & $-0,35$ & $* *$ & 0,028 & $-0,177$ & 0,532 & 1,878 \\
\hline Post-Communist German state & 0,051 & & 0,052 & 0,011 & 0,907 & 1,103 \\
\hline \multicolumn{7}{|l|}{ Individual Characteristics } \\
\hline Social class self-assessed & 0,103 & $* *$ & 0,011 & 0,117 & 0,746 & 1,34 \\
\hline Income & 0,099 & $* *$ & 0,011 & 0,105 & 0,812 & 1,232 \\
\hline Education & 0,063 & $* *$ & 0,01 & 0,085 & 0,632 & 1,582 \\
\hline Age & $-0,003$ & $* *$ & 0,001 & $-0,046$ & 0,936 & 1,069 \\
\hline Gender & $-0,035$ & & 0,021 & $-0,018$ & 0,93 & 1,076 \\
\hline \multicolumn{7}{|l|}{ Model 2: Country Effects } \\
\hline Constant & 1,121 & & 0,063 & & & \\
\hline \multicolumn{7}{|l|}{ Countries (Ref = Ukraine) } \\
\hline Bulgaria & 0,442 & $* *$ & 0,045 & 0,114 & 0,743 & 1,345 \\
\hline Croatia & 0,229 & $* *$ & 0,043 & 0,068 & 0,617 & 1,621 \\
\hline Czech Republic & 0,821 & $* *$ & 0,041 & 0,259 & 0,608 & 1,645 \\
\hline East Germany & 0,543 & $* *$ & 0,055 & 0,114 & 0,761 & 1,314 \\
\hline Estonia & 0,548 & $* *$ & 0,051 & 0,124 & 0,774 & 1,292 \\
\hline Hungary & 0,272 & $* *$ & 0,042 & 0,084 & 0,626 & 1,598 \\
\hline Latvia & 0,293 & $* *$ & 0,042 & 0,086 & 0,673 & 1,486 \\
\hline Poland & 0,595 & $* *$ & 0,046 & 0,156 & 0,706 & 1,416 \\
\hline Russia & 0,102 & $*$ & 0,044 & 0,028 & 0,697 & 1,435 \\
\hline Slovakia & 0,534 & $* *$ & 0,04 & 0,176 & 0,6 & 1,666 \\
\hline Slovenia & 0,194 & $* *$ & 0,044 & 0,055 & 0,655 & 1,528 \\
\hline \multicolumn{7}{|l|}{ Individual Characteristics } \\
\hline Social class self-assessed & 0,087 & $* *$ & 0,011 & 0,099 & 0,696 & 1,438 \\
\hline Income & 0,103 & $* *$ & 0,011 & 0,109 & 0,805 & 1,242 \\
\hline Education & 0,066 & $* *$ & 0,01 & 0,089 & 0,614 & 1,63 \\
\hline Age & $-0,002$ & $* *$ & 0,001 & $-0,032$ & 0,897 & 1,115 \\
\hline Gender & $-0,036$ & & 0,02 & $-0,019$ & 0,926 & 1,08 \\
\hline \multicolumn{7}{|l|}{$\begin{array}{l}\mathrm{R}^{2} \text { Model 1: } 0,076^{* *} \\
\mathrm{R}^{2} \text { Model 2: } 0,12^{* *} \\
\mathrm{~N}=8581\end{array}$} \\
\hline $\begin{array}{l}\text { Significance: } * * \mathrm{p} \leq 0.01 * \mathrm{p} \leq 0.05 \\
\text { Data: See Table } 3\end{array}$ & & & & & & \\
\hline
\end{tabular}


Interestingly, the former Soviet states dummy exhibits the highest Beta value and a negative effect on the DV; thus, people within this welfare regime strongly tend to support redistribution policy. However, we are also interested in the effect of individual socioeconomic characteristics on the DV. Here, an individual's socioeconomic class background turns out to have the highest impact, followed by levels of income and education. All of these IV are positively correlated with the DV, which implies that a higher socioeconomic position corresponds with the rejection of a redistributive policy. Model 2 in Table 5 takes the country effects into account and indicates that the effect of the membership in at least five countries is stronger than that of the individual socioeconomic position - four of them are associated with the Post-Communist East European states (the Czech Republic, Slovakia, Poland, Bulgaria). The positive Beta coefficient suggests that individuals from these countries tend to reject redistribution policy. In general, Hypothesis 3 is supported by the data. Particularly the first model displays significant effects of the socioeconomic position on the DV. Concerning Hypotheses 1 to 3, each of the regressions suggests that also macro characteristics (that is, objective inequality and the membership in a welfare regime or a particular country) have considerable effects on people's beliefs and perceptions about social inequality. We must note, however, that our regressions consider only individuals who have their own income. Concerning the two socio-demographic characteristics, gender has no significant impact in any of the regression models while age has a slight impact on and is negatively correlated with both DV. This means that older people tend to perceive larger income differences, and that they are more in favor of redistribution policy. This is plausible in view of the fact that they were socialized during the Communist period and many of them, now in their old age, will have experienced a deterioration in their standards of living.

The ISSP questionnaire includes two items that address typical images of stratified societies. Hypothesis 4 claims that an individual's self-attribution to a distinct type of stratified society is contingent upon his or her membership in a particular welfare regime. One item asks for the individual perception and assessment of the type of society an individual lives in, another one is about an individual's desire for a particular type. Figure 5 gives an overview of these images. Their step-like structure suggests a pattern of stratification, going from the bottom to the top, where every step equals a social stratum. 
Figure 5 ISSP Society types

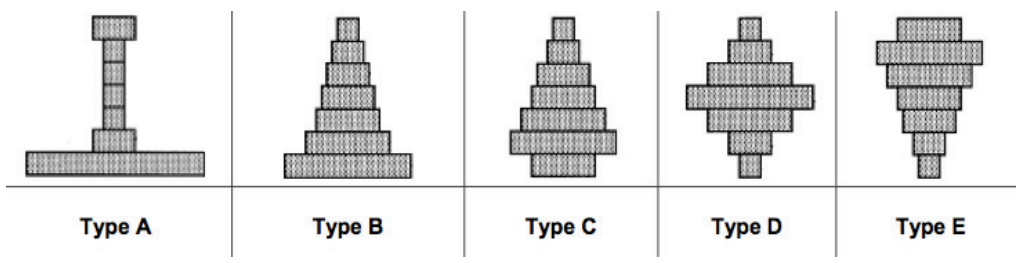

Source: GESIS (2008: 13)

Before testing Hypothesis 4, let us investigate the distribution of relative frequencies across the CEE countries as well as across the three welfare regimes on both items; i.e. the preference and the desire for a particular society type. The cross tabulation in Table 6 lists each type by its most salient features in the upper half, whereas types D and E (see Figure 5) were aggregated to one single type ("broad middle and upper class"). As a next step, we recoded both variables to dichotomous dummies that distinguish between asymmetric (types A, B, C, coded as 0 ) and symmetric types of stratification (types D, E, coded as 1$)$.

The key significance test (Pearson-Chi-Square) rejects for both items the null hypothesis, which claims that the welfare-regime types and the society types are not associated. This result further supports Hypothesis 4 since it implies a significant relationship between welfare regimes and the perception of the societal pattern of stratification. The right-hand side of Table 6 shows that most individuals in the Post-Communist former Soviet states (54\%) claim to live in a society with "a small elite at the top, very few people in the middle and the great mass of people at the bottom". A similar pattern is indicated for the Post-Communist East European states (45\%), while a third $(33 \%)$ within this welfare regime associate their society with "a pyramid with a small elite at the top, more people in the middle, and most at the bottom". The relative majority of East Germans are associated with this "distinct pyramidtype" (39\%), and about a fifth of them with the "elite vs. mass-type" (22\%) and the "weak pyramid-type" (19\%). Across all regimes, only a minority selects society types that indicate more equality, including a broader middle and upper class, except East Germans, who refer more often to such types. Aggregating the society types into a binary coded variable clearly shows the differences between the regimes, with East Germans having the lowest share $(80 \%)$ of respondents that consider their society asymmetric. Bulgaria and Ukraine show the highest proportions (96\%) of asymmetric types; also Croatia, Hungary, Latvia and Slovakia have very high shares - each with 


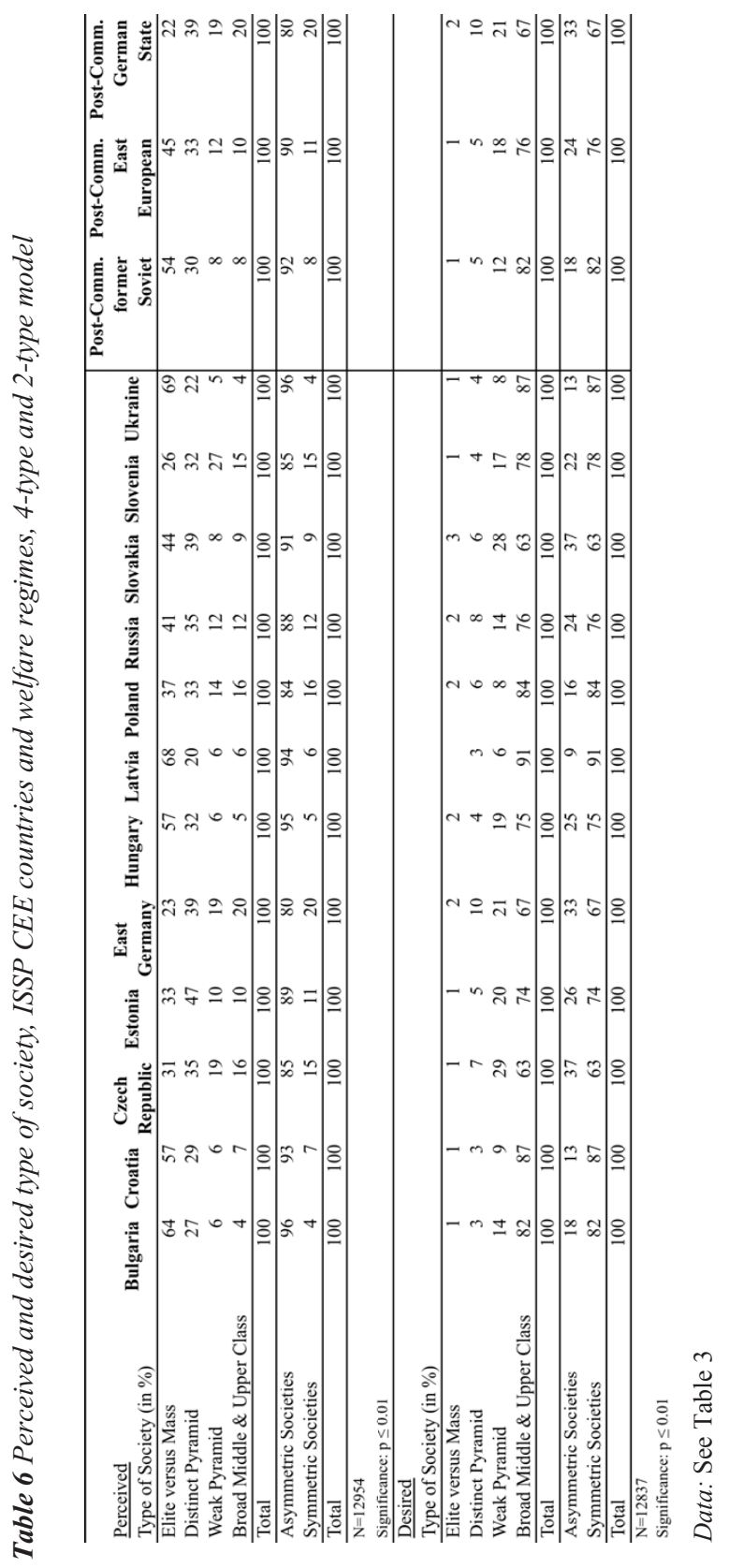


more than $90 \%$ - of people who consider their society to be stratified in this way.

To get a more comprehensive picture it is also of interest to analyze which type of society people in CEE consider desirable. The lower section of Table 6 shows the resulting figures. Here, too, the significance test confirms that welfare regime and the desire for a particular type of society are associated. However, the pattern obviously differs from what is suggested in the upper section of this table. Logically, a person who thinks of herself as living in an unjust society would most likely prefer to live in a fair society. It is exactly this inference that can be drawn from the results. The data indicate a reverse pattern, thus desire is diametrically opposed to perception. Across all welfare regimes and countries, the "broad middle and upper class-type" is the most desired, particularly so in the former Soviet states (82\%). Latvia (91\%) and Ukraine (87 \%) show the highest proportions, followed by the East European Post-Communist states (76 \%). Within this welfare regime, Croatia (87\%) and Bulgaria (82\%) have the highest share regarding desire for a symmetrical society. East Germany comes in last, with a proportion of $67 \%$.

Finally, Hypothesis 4 can be tested with a logistic regression, wherein we apply the same approach to our analysis as demonstrated with the previous regressions (i.e. two models with the identical IV and CV). The results are presented in Table 7. They support our fourth hypothesis to the extent that the membership in one of the welfare regimes has a stronger effect on the DV than the individual CV (e.g. social class, education). However, objective inequality (Gini 2009 and the change ratio) has no significant effect. 
Table 7 Logistic regression analysis of the perceived type of society, 2-type model

\begin{tabular}{|c|c|c|c|c|}
\hline Model 1: Inequality and Welfare Regimes & $\mathrm{B}$ & Sig. & SE & $\operatorname{Exp}(\mathrm{B})$ \\
\hline Constant & $-2,114$ & & 0,397 & 8,264 \\
\hline \multicolumn{5}{|l|}{ System Characteristics } \\
\hline GINI 2009 & $-0,005$ & & 0,016 & 1,005 \\
\hline GINI Change-Ratio 2009 to 1989 & 0,189 & & 0,206 & 1,208 \\
\hline Post-Communist East European states & $-0,763$ & $* *$ & 0,154 & 2,146 \\
\hline Post-Communist former Soviet states & $-1,233$ & $* *$ & 0,164 & 3,436 \\
\hline Post-Communist German state & (Ref) & & & \\
\hline \multicolumn{5}{|l|}{ Individual Characteristics } \\
\hline Social class self-assessed & 0,295 & $* *$ & 0,042 & 1,343 \\
\hline Income & $-0,039$ & & 0,043 & 1,040 \\
\hline Education & $-0,102$ & $* *$ & 0,038 & 1,107 \\
\hline Age & $-0,004$ & & 0,002 & 1,004 \\
\hline Gender & $-0,002$ & & 0,081 & 1,002 \\
\hline \multicolumn{5}{|l|}{ Model 2: Country Effects } \\
\hline Constant & $-3,315$ & & 0,243 & 27,778 \\
\hline \multicolumn{5}{|l|}{ Countries $($ Ref $=$ Hungary $)$} \\
\hline Bulgaria & $-0,503$ & & 0,296 & 1,653 \\
\hline Croatia & 0,127 & & 0,22 & 1,136 \\
\hline Czech Republic & 1,01 & $* *$ & 0,187 & 2,746 \\
\hline East Germany & 1,385 & $* *$ & 0,21 & 3,996 \\
\hline Estonia & 0,568 & $*$ & 0,235 & 1,765 \\
\hline Latvia & 0,09 & & 0,223 & 1,094 \\
\hline Poland & 1,246 & $* *$ & 0,198 & 3,477 \\
\hline Russia & 0,737 & $* *$ & 0,213 & 2,090 \\
\hline Slovakia & 0,423 & $*$ & 0,199 & 1,527 \\
\hline Slovenia & 1,095 & $* *$ & 0,195 & 2,989 \\
\hline Ukraine & $-0,503$ & $*$ & 0,235 & 1,653 \\
\hline \multicolumn{5}{|l|}{ Individual Characteristics } \\
\hline Social class self-assessed & 0,232 & $* *$ & 0,044 & 1,261 \\
\hline Income & $-0,011$ & & 0,043 & 1,011 \\
\hline Education & $-0,085$ & $*$ & 0,039 & 1,088 \\
\hline Age & 0 & & 0,003 & 1,000 \\
\hline Gender & 0,045 & & 0,082 & 1,046 \\
\hline
\end{tabular}

Cox \& Snell $\mathrm{R}^{2}$ Model 1: 0,016**

Nagelkerke $\mathrm{R}^{2}$ Model 1: 0,035**

Cox \& Snell $\mathrm{R}^{2}$ Model 2: 0,035**

Nagelkerke $\mathrm{R}^{2}$ Model 2: 0,076**

$\mathrm{N}=8213$; Significance: $* * \mathrm{p} \leq 0.01 * \mathrm{p} \leq 0.05$

Data: See Table 3 
Individuals from the former Soviet states welfare regime are about 3.4 times and those from the other East European states about 2.1 times more likely to identify their societal stratification system as asymmetrical as the $\mathrm{B}$ value indicates a negative effect on the DV. Model 2 reveals that being an East German is positively correlated with the DV and has the strongest effect. East Germans are almost four times more likely to refer to a symmetrical type of society, which stands in plain contrast to the other welfare regimes where people obviously perceive much more marked inequality. The lower half of the table also shows that the Czechs, Poles and Slovenes see their society as stratified more symmetrically.

\section{CONCLUSION}

The relationship between macro-social patterns of stratification and inequality and their perception and evaluation by members of a society has been a central issue of sociology since Alexis de Tocqueville's work on democracy and equality in America (see Tocqueville, 1981). The experience of the East European countries serves as a paradigmatic empirical case in this respect for several reasons. First, the decades-long social and political order of communism - a macro-experiment par excellence (Lenski, 1978) was formally abolished within a remarkably short time span and substituted by the economic principles of capitalism and Western democracy. This transformation involved far-reaching changes in the economic, social and political spheres. Second, Communism and Western capitalism and democracy are also competing ideologies and thus will have direct effects on individual perceptions and evaluations of inequality and equality. The revolutionary political turnaround was caused by the adverse experiences of the CEE countries' peoples with the oppressive character of Communist politics as well as its inability to keep pace with the rise of living standards in Western Europe. Critical scholars claim that the turbulent years of political and economic reforms were characterized by a neglect of redistributive mechanisms and a social policy necessary to attenuate the newly rising inequalities. Unemployment and poverty became salient and massive new social problems for most of the CEE societies. It could be argued that the failure to recognize the importance of welfare-state institutions was due to the absolute rejection of the state-socialist past and this explains why neoliberal reform approaches were welcomed euphorically and unquestioned by the national policy makers in charge and their international (mostly US-) advisers. Third, a large quantity of socioeconomic data is now available to assess 
economic performance during and after the transition, as well as changing levels of income inequality in the CEE countries. Comparison across time suggests that two decades ago inequality in CEE was at a much lower level than it is today. A key inference from our empirical findings, however, is that the mere level of objective inequality as measured by means of Gini coefficients is not positively correlated in a strong way with the subjective perception of too large income differences. An explanation for this surprising phenomenon may be that the perception of the unequal distribution of resources is mediated by socio-cultural and political institutions, in particular the mass media and public debates. It is well known, for instance, that the freedom of press to report about social problems - and these may include questions about income distribution - is restricted in Russia. Interestingly, earlier cross-sectional research beyond CEE also indicates low correlation between objective inequality and its individual perception. Further, this research shows evidence that in countries with higher economic prosperity (measured with the GDP per capita) people are less likely to perceive large income differences (Hadler, 2005; see also Kerr, 2011). The level of income inequality and economic prosperity can be a welfare-state characteristic inter alia, as demonstrated by Fenger (2007: 19, 23). Our findings show that the individuals' embeddedness in a particular welfare regime matters significantly. As opposed to the onedimensional variable income inequality, the concept of a welfare regime combines several dimensions of socioeconomic and political macro features that result in a distinct institutional structure. It also may include the different religious composition of the CEE countries. Therefore, future cross-sectional studies on CEE should also pay attention to the fact that most Post-Soviet societies are orthodox while the more Western CEE countries are catholic, and some of them (e.g. Czech Republic, Hungary) have sizable protestant minorities. Furthermore, the differences between the welfare regimes can be comprehended better through their connection to perceived images of societal stratification. Most individuals in the Post-Communist former Soviet states associate their societies with a model that indicates a very small elite at the top and most people at the bottom. Maybe many people think that there should be more differentiation within the bottom strata. On the other side, the majority of the respondents from the CEE countries desire a society with a broad middle and upper class. Therefore, it can be concluded that particularly people in Russia, the Ukraine and the Baltics might feel socially disadvantaged. Such a finding is indeed worrying and policy makers would be well advised to counteract such sources of potential political instability, national chauvinism and social unrest. The main finding concerning the more Western CEE countries is that the significant economic growth and rise of living standards 
in the region has attenuated the problem of economic inequality. However, they also face many new social problems and the CEE countries in general would be well advised to take seriously the quest of their citizens for a more balanced distribution of opportunities and life chances. A prerequisite for this will be the development of well-organized and functioning institutions of industrial and political representation of interests (e.g. unions, political parties) and that the elite-led process of transition (Haller, 1996) is substituted by true and transparent democratic systems.

\section{REFERENCES}

Adam, J. (1999): Social Costs of Transformation To A Market Economy in PostSocialist Countries: The Case of Poland, The Czech Republic and Hungary. London: Palgrave Macmillan.

Aidukaite, J. (2010). Welfare reforms in Central and Eastern Europe: A new type of welfare regime? Ekonomika 2010, 89 (4), pp. 7-24.

Aidukaite, J. (2011). Welfare reforms and socio-economic trends in the 10 new EU member states of Central and Eastern Europe. Communist and Post-Communist Studies, 44(3), pp. 211-219.

Arts, W. \& Gijsberts, M. (1998). After the Velvet revolutions: Altered Life-Chances, Fragile Legitimacy, and Split-Consciousness in Post-Communist Eastern Europe. Social Justice Research, 11(2), pp. 143-171.

Bandelj, N. \& Mahutga, M. C. (2010). How Socio-Economic Change shapes Income Inequality in Post-Socialist Europe. Social Forces, 88(5), pp. 2133-2161.

Clasen, J. (2012). Comparative social policy and the European Union. In J. Baldock, L. Mitton, N. Manning \& S. Vickerstaff (Eds.), Social Policy (pp. 396-414). Oxford: University Press.

Deutsches Institut für Wirtschaftsforschung - DIW (2005). Research Notes 2005 - 8: Naming Differences in Divided Germany. Berlin.

Djilas, M. (1957). The new class: An analysis of the Communist System. New York: Prager.

Esping-Andersen, G. (1990). The Three Worlds of Welfare Capitalism. Cambridge: Polity Press.

Fenger, H. J. M. (2007). Welfare Regimes in Central and Eastern Europe: Incorporating Post-Communist Countries in a Welfare Regime Typology. Contemporary Issues and Ideas in Social Sciences, 3 (2), pp. 1-30.

GESIS (2008). ISSP 2009 “Social Inequality IV” - ZA No. 5400. Source Questionnaire. http://www.gesis.org/issp/issp-modules-profiles/ social-inequality/2009/.

Gros, D. \& Steinherr, A. (2004). Economic Transition in Central and Eastern Europe. Cambridge: University Press.

Hadler, M. (2004). Die Mehrebenen-Analyse. Ihre praktische Anwendung und theoretische Annahmen. Österreichische Zeitschrift für Soziologie, 29 (1), pp. 53-74. 
Hadler, M. (2005). Why Do People Accept Different Income Ratios? Acta Sociologica, 48(2), pp. 131-154.

Haller, M. (1990). The Challenge for Comparative Sociology in the Transformation of Europe. International Sociology, 5: pp. 183-204.

Haller, M. (1996). The dissolution and building of new nations as strategy and process between elites and people. Lessons from historical European and recent Yugoslav experience. International Review of Sociology, 6 (2), pp. 231-247

Haller, M., Mach, B. \& Zwicky, H. (1995). Egalitarismus und Antiegalitarismus zwischen gesellschaftlichen Interessen und kulturellen Leitbildern. In H.-P. Müller \& B. Wegener (Eds.), Soziale Ungleichheit und soziale Gerechtigkeit (pp. 221264). Opladen: Leske \& Budrich.

Hradil, S. (2002). Soziale Ungleichheit, soziale Schichtung und Mobilität. In H. Korte \& B. Schaefers (Eds.), Einführung in Hauptbegriffe der Soziologie (pp. 205-227). Opladen: Leske \& Budrich.

ISSP Research Group (2012). International Social Survey Programme: Social Inequality IV - ISSP 2009. GESIS Data Archive, Cologne. ZA5400 Data file Version 3.0.0.

Ivanova, M. (2007). Inequality and government policies in Central and Eastern Europe. East European Quarterly, XLI (2), pp. 167-204.

Kerr, W. R. (2011). Income Inequality and Social Preferences for Redistribution and Compensation Differentials. NBER Working Paper No.17701.

Lane, D. (1992). Russia in flux: the political and social consequences of reform. Aldershot, Hants: Elgar.

Lane, D. (1971). The end of inequality? Stratification under state socialism. Harmondsworth, Baltimore: Penguin Books.

Leibrecht, M., Klien, M. \& Onaran, O. (2011). Globalization, welfare regimes and social protection expenditures in Western and Eastern European countries. Public Choice, 148, pp. 569-594.

Lenski, G. (1978). Marxist Experiments in Destratification: An Appraisal. Social Forces, 57(2), pp. 364-383.

Mikhalev, V. (2003). Overview: Inequality and Transformation of Social Structures. In V. Mikhalev (Ed.) Inequality and Social Structure during the Transition, (pp. 1-20). Basingstoke: Palgrave.

Örkény, A. \& Székelyi, M. (2000). Views on Social Inequality and the Role of the State: Posttransformation Trends in Eastern and Central Europe. Social Justice Research, 13(2), pp. 199-218.

Sengoku, M. (2004). Emerging Eastern European welfare states: a variant of the "European" welfare model? In S. Tabata \& A. Iwashita (Eds.), Slavic Eurasia's integration into the world economy and community, (pp. 229-255). Sapporo: Slavic Research Centre (Hokkaido University).

Snijders, T. \& Bosker, R. (2011). Multilevel Analysis: An Introduction to Basic and Advanced Multilevel Modeling. London: SAGE Publications.

Solt, F. (2009). Standardizing the World Income Inequality Database. Social Science Quarterly 90(2), pp. 231-242. 
Tocqueville, A. (1981). Democracy in America. New York: Modern Library.

Večerník, J. (2009). Czech society in the 2000s: A report on socio-economic policies and structures. Prague: Academia.

Verwiebe, R. \& Wegener, B. (2000). Social Inequality and the Perceived Income Justice Gap. Social Justice Research, 13(2), pp. 123-149.

Voslensky, M. (1984). Nomenklatura: the Soviet ruling class. Garden City, N.Y.: Doubleday. 